\title{
PERAN ILMU MANAJEMEN SARANA DAN PRASARANA DALAM UPAYA MENINGKATKAN KREATIVITAS GENERASI MILENIAL
}

\author{
Abai Manumpak Tambunan' ${ }^{1}$ Esterlina Manalu²
}

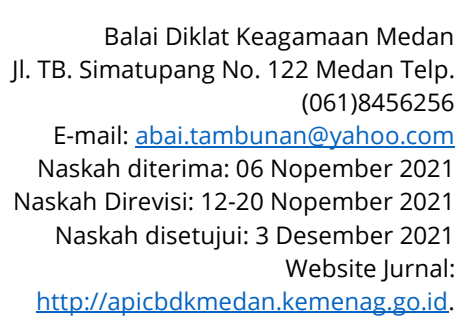

http://apicbdkmedan kemenag Jurnal:

\begin{abstract}
ABSTRAK
Artikel ini membahas tentang peran ilmu manajemen sarana dan prasarana dalam memfasilitasi generasi milenial dalam berkreativitas, untuk mendapatkan hasil yang otentik dan mendalam digunakan pola triangulasi metode, serta menggunakan analisis kualitatif dengan pendekatan studi kasus yang mengoptimalkan peran peneliti sebagai instrumen kunci, dalam penelitian ini ditemukan bahwa kreativitas generasi milenial berkembang seiring tersedianya sarana prasarana, pada bidang pendidikan, pengelola sekolah menjadikan ilmu manajemen sarana prasarana sebagai stimulus kreativitas peserta didik yang notabene golongan milenial.

Kata kunci: manajemen sarana dan prasarana, kreativitas, generasi milenial.
\end{abstract}

\begin{abstract}
Management science in facilitating the millennial generation in creativity, to get authentic and in-depth results using triangulation methods and using qualitative analysis with a case study approach that optimizes the role of the researcher as a key instrument, in this study, it was found that creativity of the millennial generation develops along with the availability of infrastructure, in the field of education, school management makes the science of infrastructure management as a stimulus for the creativity of students who are actually millennial groups.
\end{abstract}

Keywords: management of facilities and infrastructure, creativity, millennial generation

\section{PENDAHULUAN}

Berbicara sarana dan prasarana dalam implementasinya dalam masyarakat tidak dapat dipisahkan dari proses terlaksananya tugas dan tanggung jawab seseorang di sekolah, selama tahun pelajaran. terpenuhnya tujuan bersama sangat ditentukan oleh keadaan dan situasi atas proses belajarnya, untuk mengetahui rencana dan program kerja yang akan dilaksanakan perlu dirancang suatu tujuan yang optimal, sebagai bahan masukan untuk penyusunan program dan menjadi pertimbangan bagi kepala sekolah atau dalam hal ini pemimpin dalam menetapkan 
kebijaksanaan bagi kaum muda berdasarkan adanya tuntutan jaman. Langkah-langkah dalam pengembangan suatu sekolah dapat diupayakan dalam kegiatan tugas secara rinci, efektif, efesien yang merujuk pada beban kerja tertentu. Seseorang yang membidangi penguasaan manajemen sarana dan prasarana pada dasarnya memahami akan kebutuhan pendidikan baik secara individu dan kelompok. Memang secara tidak langsung hal tersebut membutuhkan peran berbagai pihak untuk ikut serta dalam mengelola dan mengembangkan kurikulum terkait kepentingan suatu golongan maka dalam prakteknya disesuaikan dengan fakta dan realita yang ada sesuai kebutuhan (Subandijah, 1993).

Adapun ruang lingkup rencana dan program kerja harus difokuskan memiliki urusan sarana dan prasarana dengan tidak lepas dari pertimbangan, masukan saran serta kritik dari berbagai elemen masyarakat sehingga membentuk sebuah program baik yang bersifat jangka pendek maupun program jangka panjang, sebagaimana mestinya sekaitan dengan esensi hadirnya manajemen sarana dan prasarana di sekolah atau lembaga pendidikan. Sumbangsi implementasi tersebut idealnya, disikapi seorang pemimpin dengan melibatkan aspek-aspek pendukung di lapangan yang kiranya mampu bersinergi agar kinerja berjalan sesuai harapan. Sekolah sendiri sebagai simbol dalam pembentukan suatu generasi dikembangkan sebagai langkah memperbaiki potensi dalam sumber daya manusia, sumber daya material yang pada hakikatnya mengandung nilai-nilai yang dapat dipahami generasi milenial sebagai hal positif yang berbentuk kegiatan beserta program-program kerja yang memihak kepada kepentingan kaum muda itu sendiri. Imbas dari hal tersebut berdampak kepada mutu pendidikan Keberadaan manajemen sarana dan prasarana yang dikelola dengan matang secara tidak langsung maupun langsung dapat menyikapi tuntutan kebutuhan generasi milenial, banyak faktor penentu seperti perbedaan geografi, demografi dan sosiologi di Indonesia terlebih saat ini Indonesia tengah menghadapi era revolusi industry 4.0 Dengan tingkat persaingan yang semakin tinggi dan sejumlah perubahan yang harus dilakukan, untuk memenuh tuntutan kebutuhan generasi milenial perlu adanya keseimbangan dengan perkembangan teknologi. Life style, kebutuhan makan dan lainnya sehingga opini yang mengeneral bahwa generasi milenial terperosok sehingga memiliki pola pikir yang buruk, bahkan sedikit diantaranya generasi milenial tersebut berpikiran apatis dengan mengedepankan gaya hidup yang semakin egosentris. Hadirnya pandangan manajemen sarana dan prasarana terhadap kebutuhan generasi milenial menjembatani berbagai problematika sehingga tantangan yang muncul dipermukaan menjadi kekuatan yang memunculkan kreativitas. Meminimalisir suatu keadaan diskriminatif dengan mengenedepankan prinsip akuntabel dimana konsep manajemen sarana prasarana dipahami sebagai tindakan yang menuntun agar bisa mengatur, mengadakan bahkan melakukan pengawasan terhadap kemajuan kebutuhan generasi milenial itu sendiri, yang mana fungsi lain atau pandangan lainnya dianggap kekuatan yang saling bersinergi dalam implementasi manajemen sarana prasarana, di sisi lain generasi milenial semestinya juga lebih peka menciptakan 
hubungan yang baik antara kebutuhannya dengan pemegang keputusan dalam sarana dan prasarana agar segala tuntutan dapat diakomodir. Kebutuhan generasi milenial merupakan aspirasi yang bisa saja merupakan kebutuhan pihak yang berkepentingan lainnya, sebenarnya merupakan amanat ketersediaan sarana dan prasarana sehingga tergambar segala upaya untuk pemenuhan kebutuhan generasi milenial. Karna setiap perubahan perubahan yang akan terjadi tidak bisa lepas dari hubungan kedua bela pihak yang pada dasarnya memberi peran satu dengan yang lain.

Dalam ruang lingkup pendidikan school based management atau manajemen berbasis sekolah generasi milenial adalah aktor utama yang berhubungan dengan aspek-aspek pendidikan lainnya hubungan ini menjadi prioritas pengamatan dan penelaan sehingga kedepannya keberadaan masing-masing komponen yang saling bersinergi serta saling mendukung untuk saling memfasilitasi pada akhirnya akan bermuara dalam peningkatan kemitraan, kualitas pendidikan, dan mutu. Berbicara mutu pastilah merupakan suatu hasil yang dapat menggambarkan adanya kepuasan sehingga upaya untuk meningkatkan mutu pendidikan ditengah perubahan global yang mana setiap siswa yang terwakili dalam panggilan atau sebuta generasi milenial itu, tercitra sebagai manusia yang cerdas, produktif dan berdaya saing dalam pergaulan nasional maupun internasional. Dalam tulisan ini penekanan peningkatan kreatifitas generasi milenial dianggap suatu keharusan karena keberadaan pola fikir mereka sangat mewarnai dinamika peradaban jaman. Tujuan dideskripsikan tulisan ini untuk menggali banyak manfaat terlengkapinya fasilitas sarana dan prasarana sebagai langkah kemajuan yang positif dalam memenuhi keinginan pihak yang membutuhkan serta dianggap mewakili kepuasan kaum milenial dan aktivitas mereka.

\section{METODOLOGI PENELITIAN}

Jenis penelitian dilaksanakan dengan pendekatan penelitian kualitatif berdasarkan pertimbangan studi kasus. Pengumpulan data menggunakan teknik wawancara, observasi, studi dokumen, wawancara dilakukan dengan beberapa informan di sekolah yang menyediakan fasilitas sarana dan prasarana yang mumpuni dalam menyerap aspek keinginan kaum milenial atau masyarakat yang menjadi stakeholde, setting dalam penelitian ini sengaja tidak dipublikasikan terkait permintaan dari pihak yang diwawancara, observasi dilakukan dengan ikut serta hadir selama 1 bulan dengan mengamati aktivitas setiap kaum milenial di sekolah sebagai pengguna layanan sarana prasarana. Instrumen pengambilan data selain penelitian sebagai instrumen kunci, juga menggunakan alat perekam serta kamera untuk mengambil foto-foto, wawancara dilakukan secara bebas, agar tidak terkesan formal dan kritis. Dengan demikian data diperoleh mengalir seperti yang diinginkan. Pertanyaan yang diajukan seputar kreativitas dan sarana prasarana. Jawaban yang diperoleh baik yang direkam maupun yang dicatat kemudian disederhanakan sesuai fokus penelitian, kemudian dianalisis dengan rujukan teori-teori yang mendukung. Observasi dilakukan dengan pengamatan secara mendalam. Laporan penelitian ini disusun dalam bentuk naratif untuk menjelaskan informasi yang diperoleh 
secara kualitatif yang kemudian digambarkan dalam jenis tulisan artikel penelitian.

\section{HASIL DAN PEMBAHASAN}

\section{A. Hasrat Generasi Millenial}

Berbicara tentang generasi milenial, dewasa ini merupakan hal yang sudah biasa didengar, apalagi di zaman era globalisasi saat ini. Menurut Elwood Carison dalam bukunya yang berjudul The Lucky Few: Between the Greatest Generation and the Baby Bloom (2008), generasi millennial digambarkan sebagai angkatan yang lahir dalam rentang tahun 1983 sampai dengan 2001. Jika didasarkan pada generation theory yang dicetuskan oleh Karl Mannheim pada tahun 1923, generasi milenial memilki makna generasi yang lahir pada rasio tahun 1980 sampai dengan 2000. Generasi millenial juga disebut sebagai generasi Y. istilah ini mulai dikenal dan dipakai pada editorial Koran besar Amerika Serikat pada Agustus 1993. Generasi ini terlahir bersamaan dengan kemajuan teknologi yang semakin meningkat, selain itu kondisi ekonomi dan social budaya yang semakin berkembang membuat generasi ini merupakan penduduk terbesar usia produktif yang memegang peran an penting untuk memaksimalkan sebuah kemajuan, sehingga peneliti mendefinisikan generasi milenial sebagai generasi yang mendapat banyak manfaat atas perubahan zaman, melihat besarnya pengaruh globalisasi terhadap kehidupan manusia terutama untuk bangsa Indonesia, baik pengaruh positif maupun negatif di era sekarang ini maka perlu adanya daya tangkal dan daya cegah masyarakat yang baik khususnya pada generasi milenial. Generasi ini memiliki ciri dan karakter yang khas dan berbeda disbanding dengan generasi sebelumnya. Dari usia mereka sangat muda dan kedepan mereka akan memegang peran yang sangat penting dalam kurun waktu 10 tahun kedepan. Sesuai dengan data BPS saat ini terdapat $50 \%$ penduduk adalah usia produktif dan berasal dari generasi milenial dan akan mencapai angka $70 \%$ dari penduduk usia produktif pada tahun 2020 sampai 2030. (Lalo, 2018). Salah satu cirri utama generasi milenial ditandai oleh peningkatan penggunaan dan keakraban dengan komunikasi, media, dan teknologi digital. di sekolah yang modern teknologi tersedia di posisikan sesunguhnya untuk memenuhi segala tuntutan milenial yang dimaksud, yang adaptif oleh kemajuan teknologi, posisi generasi milenial ini menjadi dalam posisi berbagai karakter yang melekat diantaranya bercirian kreatif, informatif, mempunyai passion dan produktif, dibandingkan generasi sebelumnya. Menanggapi hal tersebut respon seorang pengelola sarana dan prasarana disekolah menyikapi berbagai hal yang bersifat sinergis baik dengan penyediaan terkait dengan teknologi terbarukan sesuai kepentingan generasi milenial dalam segala aspek kehidupan.

Dengan adanya segala fasilitas pendukung baik sarana atau prasarana yang mereka miliki peneliti melihat angkatan tersebut semakin produktif dan efesien serta transpormatif dalam hasil belajar maupun menghasilkan banyak karya diluar pembelajaran. Sewajarnya hubungan ketersediaan fasilitas kerap menciptakan energy atau semangat dalam berkreasi, angkatan kreatif tersebut melakukan apapun sesuai maksud dan keinginan hati sehingga performa meningkat secara 
maksimal. Generasi milenial memiliki rasa ingin tahu yang sangat tinggi, mempunyai karakteristik komunikasi yang terbuka, peneliti mengamati aktifitas generasi milenial banyak mengunakan media sosial yang bahkan sampai tahap candu dan fanatik, manfaat tersedianya fasilitast eknologi untuk kebutuhan sosial media generasi milenial cukup juga berdampak dengan penguasaan ekonomi dan politik terlihat reaktif terhadap perubahan lingkungan dan dinamika kehidupan sosial. Dengan demikian penulis menganalis bahwa generasi milenial akan mudah terserap di sendi-sendi masyarakat karena wawasan mereka pada hal-hal yang baru.

Generasi milenial pada dasarnya tidak bisa dikekang dalam mengembangkan pola pikir mereka, tindakan mereka akan menjadi pasif jika prinsip ikatan dan tekanan membelenggu aktivitas mereka, pembawa kepentingan seharusnya bisa menempatkan diri untuk tercapainya suatu tujuan pengawasan memang perlu dilakukan setelah ada kesepakatan antara satu dengan yang lain, pengawasan yang dimaksud mendamping perilaku generasi milenial agar tetap sesuai adab dan kepatutan, sebagai contoh peneliti melihat interaksi generasi milenial disekolah bukan sebagai ancaman tetapi para pemilik kebijakan melihatnya sebagai suatu kesempatan untuk berubah mejadi lebih baik dengan respon positif memberif asilitas yang dibutuhkan mereka untuk berkreasi.

Memberikan pengarahan kepada mereka untuk menggunakan kesempatan yang mereka miliki dalam perkembangan teknologi di zaman era globalisasi ini. Tidak hal yang asing lagi kita dengar bahwasannya generasi milenial rentan melakukan kesalahan atas kesempatan tersebut akan kebebasan yang diberikan kepada mereka, sehingga banyak sekali generasi milenial yang rusak akibat salah pergaulan. Salah pergaulan dan pemgalaman yang belum memadai ini diakibatkan beberapa faktor, baik itu faktor internal maupun eksternal. Faktor internal yaitu faktor yang berdasarkan dari dalam diri generasi milenial tersebut, yang dimana rasa keingintahuan yang tinggi bahkan berlebihan, bahkan terlalu mudah menentukan keputusan atas sesuatu yang akan ditentukannya, padahal di era globalisasi saat ini terkhusus dari sudut pandang sosial budaya memilah atau menyaring informasi semestinya sudah menjadi kewajiban bersama tanpa memposisikan situasi golongan tertentu. Peneliti melihat peran orangtua bekejasama dengan lapisan sosial dimasyarakat terkhusus di sekolah mampu membentengi upaya yang dapat merusak pola piker mereka, peran orangtua dan berbagai pihak lain yang dimaksud sangat perlu untuk mendampingi efektif member arahan kepada generasi milenial terkait perilakunya. Faktor eksternal, yaitu faktor yang berasal dari luar lingkungan generasi milenial. Generasi milenial tidak hanya berinteraksi dengan orangtuanya dirumah, tetapi mereka pun memiliki teman-teman diluar, baik itu disekolah, ditempat ibadah, tempat nongkrong, dan lain-lain. Lingkungan yang baik akan membentuk karakter seseorang menjadi baik, sebaliknya lingkungan yang kurang baik akan membentuk karakter seseorang menjadi buruk, sehingga lingkungan yang baik dan positif sangat diperlukan oleh generasi millennial untuk berkembang kearah yang lebih baik. Apabila generasi milenial berinteraksi dengan lingkungan yang buruk, otomatis hal itu 
dapat merusak pemikiran mereka sehingga akan tercipta generasi yang temperamental. Kedua faktor ini sangat berpengaruh terhadap perkembangan generasi milenial, semakin maju perkembangan zaman tidak dapat kita pungkiri generasi milenial pasti mengikuti perkembangan tersebut, peneliti mengamati strategi member kenyamanan yang bisa saja bersumber dari ketersediaan sarana dan prasarana menjadi instrumen pengukur perubahan perilaku generasi milenial menjadi lebih baik yang kreatif dan inovatif.

\section{B. Peran IImu Manajemen Sarana dan Prasarana dalam Pendidikan}

Jika mengacu pada unsur kata, yaitu manajemen sarana dan prasarana. Manajemen adalah proses kerjasama dua orang atau lebih dalam tindakan perencanaan, pengorganisasian, pengarahan dan pengendalian yang dilakukan untuk mencapai prasarana dan sarana sekolah, sehingga keberadaannya selalu dalam kondisi siap pakai dalam setiap diperlukan oleh semua personel sekolah, manajemen juga dipahami sebagai satu proses yang khas yang terdiri dari tindakantindakan perencanaan, pengorganisasian, pengarahan dan pengendalian yang dilakukan untuk menentukan serta mencapai sasaran-sasaran yang telah ditentukan melalui pemanfaatan sumber daya manusia dan sumber-sumber lainnya, Fasilitas pendidikan dimanfaatkan sebagai factor penentu keberhasilan pendidikan. Kelengkapan dan ketersediaan fasilitas pendidikan di sekolah sangat berpengaruh terhadap keefektifan dan kelancaran pembelajaran di dalam kelas. Secara sederhana, manajemen perlengkapan sekolah dapat didefinisikan sebagai proses kerjasama pendayagunaan semua perlengkapan pendidikan secara efektif dan efisien." Berdasarkan definisi sederhana tersebut maka pada hakikatnya manajemen sarana dan prasarana pendidikan di sekolah itu merupakan proses pendayagunaan semua sarana dan prasarana yang dimiliki sekolah. (Islamic \& Manajemen, 2019).

Tujuan sarana dan prasarana diadakan untuk kepentingan generasi milenial, peneliti beranggapan perlu digiatkan dilaksanakan guna untuk mempermudah proses terjadinya belajarmengajar disetiap sekolah dan membuat generasi milenial merasakan kenyamanan dalam mencari ilmu, dengan keberadaan sarana dan prasarana pendidikan disekolah tersebut, merupakan komponen yang sangat penting dalam setiap aktifitas pendidian angkatan milenial terutama untuk menunjang kesuksesan dalam kegiatan belajar-mengajar dan minat berkarya, maka dalam pelaksanaannya setiap sekolah harus mengupayakan seoptimal mungkin dalam mengelola sarana prasarana dengan ditangani para pegawai dan dibantusetiap guru disetiapsekolah. Dan setiap sekolah harus mampu membuat perubahan sesuai kebutuhan pihak lain yang memberi rasa pembaharuan di semua bidang terkhususnya dalam bidang sarana dan prasarananya, yang mana satuan pendidikan wajib memiliki sarana yang meliputi perabot, peralatan pendidikan, media pendidikan, buku dan sumber belajar lainnya, bahan habis pakai, serta perlengkapan yang diperlukan untuk menunjang proses pembelajaran yang teratur dan berkelanjutan (IV,2010). Manajemen sarana prasarana pendidikan dapat didefenisikan juga sebagai proses kerjasama pendayagunaan semua sarana 
dan prasarana pendidikan secara efektif dan efesien. Manajemen sarana dan prasarana proses kerjasama pendayagunaan semua sarana dan prasarana pendidikan secara efektif dan efesien. Folosofi pengelolaan sarana bermula dari pengelolaan kamar mandi ini menjadi citra awal keberhasilan pengelolaan sarana sekolah yang lain. Pentingnya sarana dalam mendukung keberhasilan penyelenggaraan pendidikan serta memberikan pelayanan yang memadai kepada peserta didik guna tercapainya tujuan pendidikan, maka dibutuhkan dan didukung oleh system manajemen sarana yang baik, mengingat bahwa sarana dan prasarana pendidikan merupakan salah satu faktor yang keberadaannya sangat mutlak dalam proses pendidikan.(Fathurrahman\& Putri Dewi, 2019)

Pendidikan adalah usaha sadar dan terencana untuk mewujudkan suasana belajar dan proses pembelajaran agar peserta didik secara aktif mengembangkan potensi dirinya untuk memiliki kekuatan spiritual keagamaan, pengendalian diri, kepribadian, kecerdasan yang diperlukan dirinya karena hasil pendidikan mencerminkan keadaan pribadi dan masyarakat(Fakhruddin, 2011). Sejalan dengan itu banyak sekolah yang berlomba melengkapi dan memodernisasi fasilitas belajar-mengajar, bahkan dengan multimedia, sarana olahraga yang popular, laboratorium IPA dan fisika, sehingga dengan dimilikinya fasilitas tersebut sekolah berharap akan terbentuk citra sebagai sekolah modern dan terdepan. Dalam memenuhi sarana dan prasarana yang unggul dan diapresiasi setiap angkatan termasuk generasi milenial. Kegiatan pengelolaan bersifat terbuka dan mengakomodasi saran dan kritik dari generasi milenial yang meliputi kegiatan perencanaan, pendayagunaan, penghapusan dan penataan, dalam rangka untuk menunjang proses pendidikan guna mencapai tujuan secara efektif dan efesien. Penemuan yang berupa teknologi tepat guna dalam proses belajar mengajar atau bimbingan dan konseling serta teknologi yang bersifat lebih memudahkan pelaksanaan proses belajar mengajar atau bimbingan dan konseling dengan hasil yang lebih baik atau lebih optimal, maka dapat dipetakan proses belajar mengajar dan faktor-faktor pendukungnya harus bermanfaat untuk orang lain. Berbicara mengenai konsep sarana dan prasarana pendidikan ada standar minimum sarana prasarana Pendidikan yaitu: kriteria minimum sarana yang terdiri dari perabot, peralatan pendidikan, media pendidikan, buku dan sumber belajar lainnya. Teknologi informasi dan komunikasi, serta perlengkapan lain yang wajib dimiliki oleh setiap sekolah. Kriteria minimum prasarana yang terdiri dari lahan bangunan, ruangruang, dan instansi daya dan jasa yang wajib dimiliki oleh setiap sekolah, yang menjadi pengamatan peneliti seharusnya pengelolaan sarana dan prasarana apapun kepentingannya haruslah sesuai standar dan ketentuan yang berlaku, merujuk pendapat dalam memenuhi standar sarana prasarana yang ditetapkan oleh BNSP dibutuhkan standarisasi dan manajemen sarana dan prasarana. Ada beberapa alas an mengapa pengelolaan sarana prasarana perlu dikelola atau dimanajemen dengan baik antara lain: Karena sarana dan prasarana pendidikan merupakan salah satu sumberdaya yang penting dan utama dalam menunjang proses pembelajaran di sekolah. Pengelolaan (Bancin \& Lubis, 2017) 
Upaya agar semua fasilitas bermanfaat untuk semua pihak baik angkatan generasi milenial sehingga dapat memberikan konstribusi yang optimal terhadap proses pendidikan dan aspekaspek lainnya haruslah dikelola dengan komprehensif sarana dan prasarana yang dimaksud meliputi:(1) perencanaan; (2) pengadaan; (3) inventarisasi; (4) penyimpanan; (5) pendistribusian; (6) pemeliharaan; (7) penghapusan; (8) penilaian dan pengawasan. Hal ini menunjukkan bahwa sarana dan prasarana yang ada di sekolah dan tempat umum lainnya perlu didayagunakan dan dikelola untuk kepentingan proses pengembangan bakat diri, Pengelolahan itu dimaksudkan agar dalam menggunakan sarana dan prasarana dapat berjalan dengan efektif dan efesien. Pengelolaan sarana dan prasarana merupakan kegiatan yang sangat penting berhubungan langsung dengan peforma golongan karena keberadaannya akan sangat mendukung terhadap suksesnya proses aktivitas dalam komunitas. Manajemen sarana dan prasarana pendidikan di sekolah merupakan proses pendayagunaan semua sarana dan prasarana yang dimiliki, untuk proses menuju sebuah hasil, diharapkan semua pendayagunaan sarana dan prasarana di sekolah dapat secara efektif dan efesien menyerap semua aspirasi generasi milenial agar kiranya dampak negatif yang tidak dinginkan tidak muncul kepermukaan menyikapi pada umumnya generasi milenial mengungkapkan ketertarikan dan ketidatertarikannya melalui media sosial. (Wiridjati \& Roesman, 2018)

Sarana dan prasarana merupakan bagian integral dari keseluruhan kegiatan aktivitas komunitas yang mempunyai fungsi dan peran dalam pencapaian kegiatan sesuai harapan maka sarana dan prasarana dapat dikatakan sebagai semua komponen yang secara langsung maupun tidak langsung menunjang jalannya proses pendidikan untuk mencapai tujuan dalam pendidikan itu sendiri. Dalam inovasi sarana dan prasarana dapat ditinjau dari dua aspek yaitu: aspek fungsi dan aspek nilai. Sedangkan bentuk inovasi sarana dan prasarana dibagi menjadi dua yaitu inovasi sarana dasar dan inovasi sarana pembelajaran. Dalam hal menjadi peran manajemen sarana dan prasarana pendidikan dalam upaya meningkatkan kreatifitas generasi milenial yaitu generasi milenial disini menjadi alat ataupun dengan kata lain menjadi pemandu dalam perkembangan sarana dan prasarana ini lebih baik lagi, selain itu generasi milenial juga menjadi pengguna sarana prasarana ini. Dan disini mereka sangat dituntut dan diharapkan bisa memberikan dan menciptakan sebuah pembaharuan manajemen sarana dan prsarana yang lebih baik lagi sesuai dengan perkembangan zaman, pada kasus di Indonesia bahwa generasi milenial pada masa kini banyak menjadikan pendidikan tujuan utama mereka untuk sukses.(Oktober\& Zuber, 2011). Sehubungan dengan pada perkembangan zaman saat ini generasi milenial sudah biasa mengoperasikan bahkan sangat bersinergi dengan teknologi, fenomena tersebut memiliki pengaruh dalam dunia pendidikan khususnya. Dalam hal ini generasi milenial sangat diharapkan bisa mengembangkan prospek potensinya dan bisa memanfaatkan kesempatan serta peluang yang tersedia tersebut untuk menciptakan hal-hal baru dalam dunia 
pendidikan yang akan dirasakan manfaatnya baik langsung ataupun tidak langsung dirasakan dampaknya untuk kemajuan dan keunggulan pendidikan terkhususnya di Indonesia, seehingga generasi milenial cepat tanggap terhadap teknologi dan hal-hal baru.

\section{Manfaat kehadiran IImu Manajemen Sarana dan Prasarana Pendidikan di sekolah pada Generasi Milenial}

Pendidikan yang berkualitas harus memenuhi sarana dan prasarana yang memandai, peningkatan suatu kualitas pendidikan haruslah memenuhi standar, peneliti mengamati memang belum ada standar yang terukur di sekolah untuk kepentingan generasi milenial, tetapi sarana dan sarana pendidikan yang sudah ditetapkan oleh sekolah tersebut cukup member ruang gerak, peneliti juga mengamati selain sarana dan prasarana yang harus lengkap kualitas guru atau tenaga pendidik dan segala sumber daya pendukung dibidang pendidikan mengambil peran yang diperlukan untuk menunjang kualitas pendidikan. Sarana dan prasarana pendidikan memang belum cukup lengkap maka dampaknya terhadap proses belajarmengajar pasti terkendala, kenyamanan peserta didik saat proses belajar mengajar berlangsung tidak menggairahkan pada saat pegumpulan data, penulis melihat terbatasnya sarana dan prasarana yang menunjang pendidikan yang tidak lengkap tersebut bukan suatu keadaan yang disegaja, mengingat kebutuhan generasi milenial itu sendiri yang dominan rasa percaya diri, optimistis, ekspresif, bebas, dan menyukai tantangan, serta, memiliki keunggulan yang mana generasi milenial adalah generasi yang cukup familiar terhadap perkembangan teknologi informasi (Rudiwantoro, 2018).

Berbicara tentang manfaat manajemen sarana dan prasarana pendidikan disekolah pada generasi milenial, sebelumnya sudah dijelaskan tentang sarana dan prasarana dalam pendidikan. Sarana dan prasarana ini dapat didefinisikan sebagai kegiatan mengelola peralatan dan perlengkapan untuk menciptakan karya-karya baru, Peralatan dan perlengkapan sekolah misalnya, gedung, ruang belajar, alat pendidikan, meja, kursi dan sebagainya, peralatan dan perlengkapan ini sangatlah penting untuk menunjang proses pembelajaran, dan dewasa ini kebutuhan sarana dan prasarana generasi milenial lebih tendensi pada aplikasi dan tekonogi, Dengan kata lain kehadiran ilmu manajemen sarana dan prasarana pendidikan disekolah khususnya untuk generasi milenial dibuat memang untuk menguntungkan psikologi generasi milenial. Sarana prasarana pendidikan ini dapat digambarkan sebagai wadah untuk menuangkan semua inovasi atau penemuan-penemuan baru yang telah mereka buat, karena generasi millennial adalah generasi yang ambisius dan juga generasi millennial adalah generasi yang ingin dihargai (Setiawan \& Puspitasari, 2018).

Penulis melihat berdasarkan pengamatan dalam hal generasi milenial dalam mengejar prestasi di suatu organisasi. Generasi milenial lebih menyukai tantangan untuk promosi karena dipandang cakap dalam bekerja, menjadi hal yang menarik karena responnya didalam organisasi pasti mempertimbangkan terkait ketertarikan tersebut. 
Disisi lain perkembangan teknologi dijaman era globalisasi ini memang tidak dapat dipisahkan dari generasi milenial yang berstatus sebagai peserta didik, pada posisi ini mereka sangat diharapkan harus bisa mengasah kemampuannya untuk menggunakan teknologi dan informasi, sehingga sangat mutlak memang teknologi dan informasi ini menjadi kebutuhan penunjang aktivitas mereka, Sementara itu dengan perkembangan pendidikan yang sudah semakin maju di era milenial, generasi yang memiliki pemikiran yang kreatif, inovatif ini dapat memainkan perannya untuk membuat perkembangan dan kemajuan yang lebih baik lagi dibidang pendidikan. Peran sekolah sebagai tempat berkomunitas sangatlah penting untuk memberikan motivasi dan dorongan kepada generasi milenial untuk semakin giat belajar dan memanfaat sarana dan prasarana pendidikan dengan bijak, selain itu sekolah harus mampu memberikan wadah yang tepat sasaran bagi tempat para generasi milenial untuk menuangkan segala kemampuan-kemampuan atau inovasiinovasi yang mereka miliki, dengan tujuan memcetak generasi milenial yang berkelanjutan disamping itu peran orang tua juga dituntut bersinergi karena orang tua memiliki tanggung jawab untuk memenuhi kebutuhan anak, mengajari, mengarahkan, dan mendidik. Tanggung jawab orang tua meliputi tanggung jawab keimanan, materi, fisik, moral, akal, kejiwaan, sosial, dan seks. Tanggung jawab inilah yang disebut dengan bentuk pendidikan. Tujuan dari pendidikan itu sendiri adalah untuk membentuk anak-anak menjadi manusia yang sehat, cerdas, berkarakter mulia, berakhlak serta mampu menjadi generasi kuat dan memiliki masa depan yang cerah.(Fatmawati, 2019).

\section{SIMPULAN}

Adapun kesimpulan dalam tulisan ini menjelaskan bahwa manajemen sarana dan prasarana diupayakan untuk tindakan proses penataan dan pengelolaan yang berhubungan dengan pengadaan, pendayagunaan, inventarisasi, pemeliharaan dan penghapusan sarana dan prasarana pendidikan agar tercapai suasana belajar-mengajar yang kondusif dan nyaman sesuai dengan tujuan yang sudah ditetapkan secara efektif dan efesien.

Sedangkan tujuan pendidikan nasional tersebut pastilah seimbang dengan tersedianya fasilitas sarana dan prasarana yang memadai, untuk berkembangnya potensi generasi milenial membentuk kreativitas agar berjalan seirama menjadi manusia yang beriman bertaqwa kepada Tuhan Yang Maha Esa, berahlak mulia, sehat, berilmu, cakap, kreatif, mandiri dan menjadi warga negara yang membawa perubahan dengan tanggung jawab yang berorientasi pada peminatan mereka.

\section{SARAN}

Berdasarkan hasil penelitian dan kesimpulan yang telah dijelaskan sebelumnya, peneliti memberikan saran bahwa sekolah hendaknya menjamin tersedianya layanan manajemen sarana dan prasarana pendidikan disetiap sekolah secara langsung atau pun tidak langsung membantu terserapnya aspirasi dalam suatu kegiatan dari setiap individu serbagai pemangku kepentingan yang mana secara terkhusus generasi milenial yang dianggap siap mengikuti perkembangan zaman. 
Sebagai alat pembentuk kreatifitas tersebut, generasi milenial dianggap juga berperan menjadi media pengerak perubahan sehingga pandangan terhadap generasi milenial dalam hal kreasi benar mampu menciptakan hal-hal baru yang diharapkan bermanfaat bagi kehidupan berbangsa.

\section{DAFTAR PUSTAKA}

Bancin, A., \& Lubis, W. (2017). Manajemen Sraana Prasarana Pendidikan (Studi Kasus SMA Negeri 2 Lupuk Pakam). Jurnal Educandu, 10(1), 62-69.

Fakhruddin, A. (2011). Prinsip-Prinsip Manajemen Pendidikan Islam dalam. Jurnal Pendidikan Agama Islam - Ta'lim, 9(2), 199-212.

Fathurrahman, F., \& Putri Dewi, R. O. (2019). Manajemen Sarana Dan Prasarana Pendidikan Dalam Mendukung Proses Belajar Siswa Di Sdn Puter 1 Kembangbahu Lamongan. Jurnal Reforma, 8(1), 178. https://doi.org/10.30736/rfma.v8i1.141

Fatmawati, N. I. (2019). Literasi Digital, Mendidik Anak Di Era Digital Bagi Orang Tua Milenial. Jurnal Politik Dan Sosial Kemasyarakatan, 11(2), 119-138.

Islamic, J., \& Manajemen, E. (2019). p-ISSN: 2541-383X e-ISSN: 2541-7088. 4(1), 7792. https://doi.org/10.15575/isema.v3i2.564 5
IV, B. (2010). Manajemen Aset SaranaPrasarana Sekolah. (Buku IV).

Lalo, K. (2018). Menciptakan Generasi Milenial Berkarakter dengan Pendidikan Karakter guna Menyongsong Era Globalisasi. IImu Kepolisian, 12(2), 68-75.

Oktober, A., \& Zuber, A. (2011). Jurnal Sosiologi DILEMA. 27(2), 92-100.

Rudiwantoro, A. (2018). Langkah penting generasi millennial menuju kebebasan finansial melalui investasi. Moneter Jurnal Akuntansi Dan Keuangan, 5(1), 4451.Retrievedfromhttps://ejournal.bsi.ac. id/ejurnal/index.php/moneter/article/vi ew/2502

Setiawan, S. A., \& Puspitasari, N. (2018). Preferensi Struktur Organisasi Bagi Generasi Millenial. Jurnal Borneo Administrator, 14(2), 101-118. https://doi.org/10.24258/jba.v14i2.336

Subandijah. (1993). Suatu Mekanisme . Administrasi Kurikulum Masa Kini Oleh Subandijah. Ca, 13-23.

Wiridjati, W., \& Roesman, R. R. (2018). Fenomena Penggunaan Media Sosial dan Pengaruh Teman Sebaya Pada Generasi Milenial Terhadap Keputusan Pembelian. Jurnal Manajemen Dan Pemasaran Jasa, 11(2), 275. https://doi.org/10.25105/jmpj.v11i2.295 0 